Restoring the Balance: The Patentability of DNA-Related Technology in the US and Europe

Minssen, Timo

Publication date:

2009

Document version

Early version, also known as pre-print

Citation for published version (APA):

Minssen, T. (2009). Restoring the Balance: The Patentability of DNA-Related Technology in the US and Europe. http://papers.ssrn.com/sol3/papers.cfm?abstract_id=1482966\&download=yes 


\title{
Restoring the balance: The Patentability of DNA-related Technology in the USA and Europe
}

\author{
by Timo Minssen*
}

Scholarship speech prepared for the AWAPATENT Foundation for the Promotion of Scientific Research in the Area of Intellectual Property Rights, Operaterassen Stockholm, Jan. 27 $7^{\text {th }}, 2009$

Distinguished Guests,

Esteemed clients, partners and employees from AWAPATENT,

Ladies and Gentlemen,

Let me begin with my little speech by emphasizing my severe gratefulness for the very generous grant I received from the AWAPATENT Research Foundation, which currently helps me through the very last stages of my research project prior to its publication. I feel further very much honored to have been invited to this wonderful event and to have been given the opportunity to deliver a brief speech on the topic of my $\mathrm{PhD}$ thesis in front of such an distinguished audience.

Since I will have to follow a rather strict time-scheme I will now turn directly to the very reason for which I am standing here, and that is my nearly completed $\mathrm{PhD}$ thesis. On the first pages of my thesis you will find the following famous quote by Thomas Stearns Eliot:

"We shall not cease from exploration. And the end of all our exploring will be to arrive where we started, and know the place for the first time."

Bearing this sophisticated quote in mind let me first elucidate the starting point of my little academic endeavor and describe the questions that I had to face.

On 7 March 1953 the two young scientists, James Watson and Francis Crick, announced to fellow patrons of the Eagle pub in Cambridge that they had found "the secret of life". Only a few weeks later, on 25 April 1953, they published an article in the famous Nature magazine and announced:

"We wish to suggest a structure for the salt of deoxyribose nucleic acid (D.N.A). This structure has novel features which are of considerable biological interest."

The short article is a brilliant example of clarity, precision and British understatement. What Watson and Crick actually proposed was the winding double helix structure of DNA, which immediately suggested how DNA would replicate itself. Less than 900 words later they concluded on the same page with the simple sentence:

\footnotetext{
* Jur.lic., LL.M., M.I.L., Univ. adj. at Lund University (Sweden). Opinions expressed by the author do not necessarily represent the views of AWAPATENT AB.
} 
"It has not escaped our notice that the specific pairing we have postulated immediately suggests a possible copying mechanism for the genetic material."

Their proposed model had great beauty and simplicity. However, most significant was that it fitted to the experimental data available. Thus, it did not take long until the scientific community accepted the model as being correct and a true breakthrough. ${ }^{2}$ While this paper can be regarded as the first step into a new era of genetics which in 1962 was rightfully awarded with a Nobel Prize ${ }^{3}$ more than 50 years later DNA related technology is still at the centre of public debate.

On the one hand, the spectacular development of DNA related sciences during the last decades led to a technological and medical revolution. Due to the far reaching possibilities connected to this technology, it is the focus of many people's interest and one source of the hope that one day we will find cures for many terrible illnesses. One has only to take a look on the more recent Nobelprizes that have been awarded in the new millennium, to get an understanding of the immense impact that modern DNA-related technology has had and presumably will continue to have on the development of pharmaceuticals and other industrially useful products. ${ }^{4}$ Accordingly, DNA related science has become a highly important economic factor in global business and research.

On the other hand, the public has been made much more concerned about the level of knowledge about the human blueprint and how it is applied and commercialized. The debates are highly emotional and raise numerous complex socio-ethical, economic scientific and legal questions. At the same time, these discussions must continuously adapt to the rapidly evolving technology which is generating breathtaking novel insights about the previously unforeseen complexity of DNA molecules and proteins, the uses they can be applied for, and the various processes they are involved in. Future policies will e.g. have to consider new nanotechnological applications and developments, as well as complicated epigenetic mechanisms that were shown to play an important role in gene-expression and protein synthesis. ${ }^{5}$

\footnotetext{
1 J.D. Watson \& F.H.C. Crick, Molecular Structure of Nucleic Acids, in: Nature No. 4356, p. 737 (April 25th 1953).

${ }^{2}$ Cf. Carina Dennis and Richard Gallagher (ed.), The Human Genome (Palgrave 2001), at 16.

${ }^{3}$ See: The Nobel Prize in Physiology or Medicine 1962, which was awarded to Dr. Francis Crick, Dr. James Watson, and Dr. Maurice Wilkins "for their discoveries concerning the molecular structure of nucleic acids and its significance for information transfer in living material", more information is available at: http://nobelprize.org/nobel_prizes/medicine/laureates/1962/ (last visit: October, 23 $3^{\text {rd }}$, 2008).

${ }^{4}$ For example: Among the eighteen Nobel Prizes that were awarded from 2000 to 2008 in the categories Physiology or Medicine (1) and Chemistry (2), at least twelve achievements were directly or indirectly concerned with, or based on, DNA and protein related processes and phenomenons. More information is available at: http://nobelprize.org/nobel_prizes/lists/2008.html (last visit: November, 1st, 2008).

5 For further information, see e.g. Jeremy Moore, Scientists develop new, more sensitive nanotechnology test for chemical DNA modifications (Sept. 24th, 2008), available at: http://www.innovations-

report.de/html/berichte/biowissenschaften_chemie/scientists_develop_sensitive_nanotechnology_t est_118943.html, Wiley-Blackwell, Nano-Softball made of DNA (April, 1st 2008), available at:
} 
Unsurprisingly, the debate is particularly fierce with regard to the question of whether it should be possible to patent the results of DNA-related technology, be it in the form of novel DNA sequences and the uses for those sequences or in the form of the proteins that are encoded by such sequences. In the often heated discussions there are, by and large, two diametrically conflicting schools of thoughts:

Some people believe for multiple different reasons that DNA, an in particular human DNA, is much more than a mere chemical structure. They argue that DNA is the embodiment of the code of life and that it should be regarded as part of the common heritage of mankind. They believe that any form of patenting DNA, or of the natural processes it is involved in, is utterly wrong. Some patent opponents go even further and argue for a regime that would also ban the patents on any kind of proteins. ${ }^{6}$

Others, i.e. in particular the life science industry, argue that DNA and proteins are simply chemical compounds, albeit complex ones. Thus they take the view that it, at least in principle, should be possible to grant patents on isolated DNA sequences ${ }^{7}$ and the proteins that are encoded by it. In the past years, legislators and patent authorities have basically followed this line of thinking. As a consequence, both in Europe and in the US the grant of DNA related patents and their encoded products had become routine.

While it seems to be extremely difficult, if not impossible, to find a compromise between these fundamentally different views, the purpose of my thesis is, however, primarily related to a third area where diverging opinions can be detected. Recognizing the immense importance of patents for technology transfer and, in particular, for the risky, extremely time-consuming and incredibly expensive development of "top quality" pharmaceutical products, my research focuses on the fierce discussions among those who principally support patents on DNA -related technology over particular threshold-requirements for receiving such patents, the appropriate scope of its protection and its exclusionary effects. Among other things it is feared that too lenient standards for the granting of patent rights in upstream research might lead to patent thickets caused by far too many trivial patents and royalty stacking which - in combination with the

http://www.firstscience.com/home/news/breaking-news-all-topics/nano-softball-made-of-dna-page2-1_45564.html (last visit: November 1st, 2008); Rothstein, Mark A., Cai, Yu Cai and Marchant, Gary E., The Ghost in Our Genes: Legal and Ethical Implications of Epigenetics (June 3, 2008). available at SSRN: http://ssrn.com/abstract=1140443 . Interestingly, the Nobel Prize in Physiology or Medicine which was awarded to Andrew Z. Fire and Craig C. Mello in 2006 "for their discovery of RNA interference - gene silencing by double-stranded RNA" was concerned with one of the epigenetic mechanisms which now is also becoming a major issue in patent law. More information is available at: http://nobelprize.org/nobel_prizes/medicine/laureates/2006/ (last visit: November 1st, 2008).

${ }^{6}$ Particularly the so called "product and process of nature doctrines" could be mentioned in that context, which can still be found in both the European and the US debate.

7 i.e. new, inventive, useful and well described DNA sequences that were isolated from their natural environment by human intervention. 
specific market behavior of some patent holders - ultimately will have a negative effect on beneficial research and downstream product development (Tragedy of the anticommons). (Potential) anticommons problems, have been reported in the literature in a broad variety of novel technical fields relating to technologies such as climate-related technology computer-related technology, nanotechnology, and in particular biotechnology and diagnostic testing. 8 Quite recently even the preliminary EC Commission's report of the Pharma Sector inquiry has pointed towards this potential problem (although the conclusions that were drawn are ferociously debated). ${ }^{9}$

Related to this debate is also the discussion concerning the proper scope of protection that should be conferred to DNA-related patents. In particular, the specific issue of so called full product patents on DNA- and protein sequences whose functions have not fully been understood is in the light of novel scientific insights heavily discussed. This debate is especially fierce in the context of patents on human DNA sequences and has pursuant to political and judicial pressure led to quite drastic, incoherent legal responses. As a matter of fact, some EC Member states have now introduced various legislations that only allow purpose bound product protection for (human) DNA sequences and, in some countries, even for proteins. This legislative activity has unfortunately led to a range of legal and practical problems. Additionally, it seems not to have taken due account of recent data which reveals that even in patent systems which still allow for full product protection, the patent activity is thanks to scientific developments and a more stringent application of the traditional patentability requirements, already shifting from the patenting of isolated compounds to the patenting of novel uses and methods that have been developed with such sequences.

Yet, it should also be emphasized that even more robust and narrow patent claims may in the course of technological advances still lead to patent thickets

\footnotetext{
8 Compare F.M Scherer, The Economics of Human Gene Patents, 77 Academic Medicine (2002), at 1363 (arguing that this problem is analogous to conditions on the Rhine River durng the $18^{\text {th }}$ century), M. A. Heller and R. S. Eisenberg, Can Patents Deter Innovation? The Anticommons in Biomedical Research, Science 1 May 1998: Vol. 280. no. 5364, pp. 698 - 701. Several authors have reported potential anticommons problems relating to diagnostic testing via genes, e.g. B. Verbeure et. al, Patent pools and diagnostic testing TRENDS in Biotechnology Vol. 24 No. 3 March 2006 115-120. M. M. Hopkins et.al, DNA patenting: the end of an era? Nature Biotechnology 25, 185 - 187 (2007) who do not see any present signs of anticommons but warn that such may come. A similar conclusion on software is found in J. Bessen and M. J. Meurer, Patent Failure, 2008 pp. 190-193. The 2003 FTC Report, To Promote Innovation: The Proper Balance of Competition and Patent Law and Policy, p. 6 (see also the 2007 FTC report). See further Rubinfeld, D. L. and Maness, R., The Strategic Use of Patents: Implication for Antitrust pp. 85-102 in F. Lévêque and H. Shelanski, Antitrust, Patents and Copyright- EU and US Perspectives, 2005, p. 88.

${ }^{9}$ See Commission (2008b), Pharmaceutical Sector Inquiry - Preliminary Report, DG Competition Staff Working Paper 28.11.2008. At present a lot of criticism is presented at the Commission's homepage. It remains to be seen how much of this criticism will be reflected in the final report which can be expected before next summer. Se in particular the speech by Rt. Hon. Sir Robin Jacob, which is available at: http://ec.europa.eu/competition/sectors/pharmaceuticals/inquiry/index.html (last visit January 19th 2009).
} 
and anticommons problems. ${ }^{10}$ It is thus clear that this issue requires further monitoring taking into account novel insights from economic studies and scientific developments.

My thesis therefore takes a similar position as SOU 2008:20. In the absence of any further evidence and in the face of the more recent developments, I think that there is at present no immediate need to introduce such radical steps like a categorical purpose bound product protection into patent legislation. Yet, the situation should be monitored. Moreover, I believe that (pro-)active measure that might have to be taken should also carefully consider more flexible post- grant solution models before introducing fundamental changes into the patent system. ${ }^{11}$

What I have described so far might give the false impression that I am simply claiming that the opposition and the radical legislative reaction was merely caused by a lack of knowledge of the existing checks and balances already present in the patent system. The present situation is, however, far more complicated:

In a time were the complexity of DNA expression and application became more and more apparent, while the USPTO continued to regularly grant full product patents on DNA sequences which could arguably be isolated with a reasonable expectation of success by applying routine methods, in a time where US patents were granted on methods of swinging a swing and a crust-less peanut butter sandwhich, in a time where the patent offices on both sides of the Atlantic are still facing several hundred thousand patent applications per year while a considerable backlock of patent applications still exists, and in a time were numerous so called patent trolls are lurking under the bridge, waiting for creative developers of new products to be locked in a market before threatening them with their trivial, undeveloped patents in order to seek rent either through licensing or litigation, I think it cannot be ignored that the current criticism of the patentability rules was indeed also raising some serious questions about the proper interpretation of the patentability requirements and about the procedural system in which these patents are granted and enforced.

More specifically, my thesis therefore investigated how the European and US Patent systems interpret and apply the traditional basic patentability

\footnotetext{
10 M. M. Hopkins et.al, DNA patenting: the end of an era?, Nature Biotechnology 25, 185 - 187 (2007) at p. 187: "For now, we contend that the potential negative impact of the many patent applications filed during the build up to the publication of the Human Genome Project may be less than many have feared. However, we add a caveat. Although the increasing tendency of patent offices to grant patents claiming DNA with narrower scope and more robust claims is to be welcomed, assignees in our study indicated that they are responding by filing patents claiming splice variants and SNPs. The possibility of a corresponding upswing in the number of DNA patents entailing narrower claims could reopen concerns about an anticommons effect. Although we acknowledge that there is as yet little evidence to go on,, such a prospect is best countered by vigilance in the application of the criteria for patentability, particularly inventiveness, by patent offices."

11 See further below.
} 
requirements vis-à-vis DNA related inventions. Besides describing and evaluating the de lata situation through analysis of the most recent case law and regulations, this thesis also presents de lege ferenda proposals. In that regard special attention has been given to the above described debate over the so called "Tragedy of the Anticommons" . Recognizing that the gravity of "anticommons" scenarios is difficult to prove ${ }^{12}$ and also depends on a variety of "pre-grant" and "post-grant" factors that fall outside the scope of the analysis, my thesis highlights the importance of a well balanced and stringent application of the central patentability requirements in order to achieve enforceable, well defined "high quality" patents which may either forestall or moderate (potential) anticommons situations, or at least provide a sound basis for more comprehensive solution models that try to tackle such situations at the post grant level.

So, what is a "high quality" patent and how can we achieve such "high quality" patents? In my view one of the basic features of a "high quality patent" is that it is enforceable, well defined and - what is most important - that it corresponds to the actual technical contribution that the inventor as provided to the state of the art. Particularly, in the pioneering phase of emerging technologies, I believe that this must in some cases allow the strong protection that can be achieved by granting full product protection - although as technology matures I think that such strong/broad protection should be increasingly limited to very exceptional cases. I also think that both in the US and Europe, a thorough examination of each case on its own merits should (in combination with flexible post-grant solution mechanisms) indeed achieve the goal of granting (and enforcing) claims of a format and scope which corresponds to the actual technical contribution to the state of the art by the patent application/patent. This should in the most cases alleviate the effects of what is perceived by some as a far too liberal patent system granting excessively broad protection to DNA related inventions. ${ }^{13}$

By scrutinizing systematically how the US and European Patent offices and courts interpret and apply the basic patentability criteria with regard to DNA related inventions, my thesis demonstrates that the US and European patent systems have reacted to the challenges and are already on the right track although many problems still remain. A closer look on the interpretation and effect of the novelty requirement reveals for example that the publication of

\footnotetext{
12 Compare Holman, "The Impact of Human Gene Patents on Innovation and Access: A Survey of Human Gene Patent Legislation", Berkely Center for Law and Technology", paper 43 (2008), available at http://repositories.cdlib.org/bctl/lts/43 (last visit Januray 10th 2009), who warns at p. 67 , that "Without more compelling evidence of an overwhelming negative impact in contexts that are critical to the public good, there is no adequate justification for rushing into a radical legislative fix that might have substantial unintended negative consequences." See also Caulfield et al, "Evidence and anecdotes: an analysis of human gene patenting controversies", in: Nature Biotechnology 24(9):1091-1094 (2006).

13 This view is shared by Galligani in his contribution to the 13. symposium of European patent judges in Thesaloniki 12. - 16. September 2006, available in De., En. and Fr., special edition 2/2007 OJ EPA., 148 - 16 (156); available at: <http://www.european-patentoffice.org/epo/pubs/oj007/04_07/special_edition_2_judges_symposium.pdf $>$ (last visit March, 11 $1^{\text {th }}$ 2007).
} 
almost all human DNA sequence information by the Human Genome Project, and the increasing volume of various protein data banks has made it much more difficult to establish novelty of a sequence as such. Moreover, the mere fact that the methods for identifying and isolating sequences have become increasingly routine has led to a situation, where it has become much more difficult to fulfill the European inventive step requirement if the sequence in question had not been extraordinarily difficult to find or had surprising properties. After the US Supreme Court had delivered its famous KSR decision in 2007 and in particular after following the USPTO decision in Ex parte Kubin (which is now In re Kubin and pending at the CAFC - oral proceedings were held only a couple of days ago), it has become equally difficult to fulfill the US nonobviousness criterion if their was a reasonable expectation of success to arrive at the invention.

Moreover, recent case law and examinations guidelines in the US and Europe have shown that the information (be it information based on in silicio or wet biology experiments) which is delivered in connection with the patent application must be of such a quality that it is made at least plausible that a solution to the underlying problem and a profitable use had been found and disclosed, otherwise this can result either in a objection based on lack of inventive step (see for example, T 1329/04 where it was found that no plausible solution to the underlying technical problem was disclosed), or lack of industrial application (see for example T 870/04 and in In re Fisher ${ }^{14}$, where no profitable and immediate use for the "real world" or industry was found to be disclosed - see also recent UK cases $\left.^{15}\right)$.

Also the thresholds for the sufficient disclosure requirement have been recently heightened both in Europe and in the US. It will for example no longer be sufficient to give a vague indication of a possible medical use of compounds which would still have to be identified. The EPO would consider this to amount to a fundamental, incurable insufficiency of disclosure (T609/02). Once again, similar developments can be detected in the US, where already the KSR inspired USPTO decision in Ex Parte Kubin has been triggering "early" (i.e. without waiting for In re Kubin ${ }^{16}$ ) changes in the US examination guidelines for the written description requirement that point towards a more strict, possession based line of case law. In that respect the In re Kubin decision that we can expect by the CAFC within the next 90 days, will be of tremendous importance for the biotech industry. Unfortunately, I will not have the time to go further into the details here.

To sum it up, I think that my research shows that the checks and balances already existing within the current patent system can tackle many problems if they are properly and strictly applied. In the face of vigorous attacks of the

\footnotetext{
${ }^{14}$ Cf. In re Fisher, 421 F.3d 1365 (Fed. Cir. 2005).

15 See eg. Eli Lilly \& Company v. Human Genome Sciences, Inc. EWHC 1903 [31 July 2008], available at: http://www.bailii.org/ew/cases/EWHC/Patents/2008/1903.pdf (last visit August, 1 2008).

${ }^{16}$ In re Kubin, CAFC App. No. 2008-1184, Ex parte Kubin, 2007 WL 2070495 (PTO Bd. App.\& Int. 2007) (Linck, AP).
} 
patent system it will therefore be utterly important to communicate these positive effects and the ratio of the patent system to the public and the research community.

In that regard it should also be underlined that the system should be well balanced, and, in particular, that not everything should be and can be solved by an increasingly strict application of the patentability rules, without risking to hamper an effective innovation system that builds on incremental scientific steps (with regard to the research tool issue), legal certainty, as well as practicability and predictability.

I believe that sustainable solutions can only be achieved if those changes in patent law \& procedure that are absolutely indispensable are accompanied by changes on the post grant level, taking into consideration a more coherent interpretation of research exemptions, competition law, procedural changes in patent litigation, a more flexible doctrine of equivalence and more elaborated/uniform guidelines on patent pools, clearing houses or other private ordering/licensing solutions. ${ }^{17}$ (yet, I think that compulsory licensing should remain a last resort, which should only be taken into consideration in extreme situations).

Numerous recent patent related judgments by US and European $\operatorname{courts}^{18}$ that have stipulated novel patent examination guidelines and decisions by the patent offices, as well as various legislative reform initiatives, indicate that decision makers on both sides of the Atlantic seem to share this view and have started to address the numerous challenges that lay ahead of us accordingly.

If these changes are conducted carefully and acknowledge and respect the importance of a well balanced patent system, I think that modifications of the

\footnotetext{
17 With regard to ordering solutions compare e.g. F. Scott Kieff and T. A. Paredes Engineering a Deal: Toward a Private Ordering Solution to the Anticommons Problem Stanford Law and Economics Olin Working Paper No. 330 , Washington University School of Law Working Paper No. 06-12-01 (available at SSRN=948468) at p. 2.

18 As for the US Supreme Court see for example Quanta Computer Inc. v. LG Electronics Inc., 128 S.Ct. 2109 (2008) [exhaustions doctrine], KSR International Co. v. Teleflex Inc., 82 USPQ2d 1385, see also 38 IIC 735 (2007) [non-obviousness]; MedImmune, Inc. v. Genentech, Inc., 81 USPQ2d 1225 (2007) [jurisdiction in declaratory judgment actions] and Microsoft Corp. v. AT\&T Corp., 82 USPQ2d 1400 (2007) [applicability of the US Patent Act with regard to foreign duplication of software]. See also the 2006 decisions in eBay Inc. et alia v. MercExchange, L.L.C., 78 USPQ2d 1577 (2006) [injunctive relief in patent infringement suits], and Labcorp v. Metabolite, 79 USPQ2d 1065 (2006) [patentable subject matter-dismissed as improvidently granted], as well as the 2005 decision in Merck KGaA v. Integra Lifesciences I, Ltd., 545 U.S. 193 (2005) [interpretation of 35 U.S.C. $§ 271$ (e) (1)], which was followed by several interesting CAFC decisions. See also further extremely important decisions which might end up in the Supreme Court, such as Bilski v. Doll, Supreme Court No. 08-964, and_F.3d_ (Fed. Cir. 2008) (en banc) (Michel, C.J.) [patent eligibility]. Compare in addition the recent antitrust judgments in FTC v. Rambus, Supreme Court No. 08-694, Rambus v. FTC, 522 F.3d 456 (D.C. Cir. 2008) (Williams, J.) [SSO Antitrust Petition]. As for European competition law related decisions see in particular C T201/04 Microsoft Corp. v EC Commission, C-498/06 to C-478/06 GlaxoSmithKline andCase COMP/A. 37.507/F3 AstraZeneca.
} 
legal rules on the post-grant level might give us an efficient "surgical" tool to carefully counterbalance the potential negative effects that patents might have.

Ladies and gentlemen, this brings me to the end of what I wanted to say to you. Let me now conclude by returning to my starting point and that is the quote by T.S. Eliot:

"We shall not cease from exploration. And the end of all our exploring will be to arrive where we started, and know the place for the first time."

So, how does it feel now, standing there? Do I really know the place for the first time? Well, to some extend I do. I could point out - or give at least a qualified prediction on - various negative and positive effects that would result from various interpretations of the basic patentability requirements with regard to DNA-related technology. I even achieved some kind of understanding of how the various issues that are raised on the pre- and post-grant level are related which each other, and I learned more about the delicate balance between competition law and patent law, although I only focused on the latter. But what is more important in that context is that I do know more about, what I do not know.

Having reached the end of my $\mathrm{PhD}$ journey I became even more fascinated over the amazing complexity not only of the technology, but also of the legal framework and the socio-economic impact of the legal rules and the practice that tries to regulate its commercialization in a utilitaristic way. I feel like I managed to put one or two pieces of a puzzle into the right place, although the optimal solution might consist of at least 100 pieces. At the same time, I believe that this is going to be an eternal puzzle and that perhaps the complete and perfect solution will never be revealed, since the shape of the perfect solution is continuously shifting in the face of technological, economic and sociological changes.

In that regard, it is perhaps better to speak of a calibration or weighing process, where the ultimate goal is to find a dynamic balance between competing and interacting values, such as access to technology and health care, dynamic and static competition, as well as the goal to provide incentives for research through securing the return of investments in order to achieve the greatest public good. It is then my hope that interdisciplinary research will develop its channels of communication and finally bring together academics and practitioners from various scientific fields in order to refine the system both on the pre- and postgrant level. This might make it possible to at least narrow down the amplitude in which the scale ${ }^{19}$ should be allowed to swing and thereby to reduce the costs of the system and increase its benefits.

How this could exactly be achieved would be the ultimate finding of any related $\mathrm{PhD}$ thesis which would probably deserve a price equal to a Nobel price. The ultimate finding of my thesis is far less ambitious, if not to say humble, and can

\footnotetext{
19 more commonly it is often referred to a pendulum.
} 
for some reason be detected in the great majority of academic findings. It boils down to this:

"We need more research"

Thank you very much for your attention. 